\title{
Ślady zapomnianej tożsamości. O roli źródeł w biografii Janusza Korczaka
}

\author{
Marlena Sęczek \\ ORCID: 0000-0003-I203-7IIO \\ (Instytut Badań Literackich PAN, Warszawa)
}

Od wierności w rzeczach matych zawsze zależy
powodzenie flologa i biografa.
Wiesław Ratajczak

„W moich licznych, nieomal codziennych kontaktach z ludźmi, którzy interesują się Korczakiem i chcieliby o nim jak najwięcej wiedzieć, przekonuję się na każdym kroku [...], że potoczna wiedza o [nim - M. S.] jest raczej nikła, fragmentaryczna i powierzchowna" ${ }^{2}$ - pisał w 1999 roku Aleksander Lewin. W swojej książce Korczak znany i nieznany ów niepokój badacz formułował wielokrotnie, ubolewając nad tym, że legenda narosła wokół Pana Doktora przesłoniła fakty wyznaczające linię życia tej skomplikowanej postaci. Zgadzając się z tą diagnozą, trzeba dodać, że przyczyną takiego stanu rzeczy nie jest bynajmniej brak opracowań biograficznych o Korczaku.

Pierwsza próba zebrania danych biograficznych o słynnym pedagogu, lekarzu i pisarzu, ogłoszona przez Hannę Mortkowicz-Olczakową w I949 roku, dała początek całej serii prac o zbliżonym charakterze ${ }^{3}$. Jednak publikowane mniej więcej

1 W. Ratajczak, O potrzebie wierności drobiazgom, „Poznańskie Studia Polonistyczne. Seria Literacka” 2019, nr 35 (55), s. 411.

2 A. Lewin, Korczak znany i nieznany, Warszawa 1999, s. 5.

3 Zob. H. Mortkowicz-Olczakowa, Janusz Korczak, Warszawa 1949 i wyd. nast., m.in. wyd. od drugiego do piątego w 1957-1978, oraz m.in.: I. Newerly, Żywe wiazanie, Warszawa 1966, wyd. drugie i trzecie w 1967, 1971; M. Jaworski, Janusz Korczak, Warszawa 1973, wyd. drugie i trzecie w 1977, 1978; A. Szlązakowa, Janusz Korczak, Warszawa 1978; S. Wołoszyn, Korczak, Warszawa 1978, wyd. drugie 1982; K. Dębnicki, Korczak z bliska, Warszawa 1985; B.J. Lifton, The king of children, New York 1988. 
raz na dekadę, w Polsce i za granicą, życiorysy Janusza Korczaka w znikomym stopniu modyfikowały zasób wiedzy z tego zakresu. Kolejni autorzy zasadniczo powielali ustalenia poprzedników, przepuszczali znane fakty przez filtr własnej wrażliwości i - stosownie do panujących w nauce trendów - eksplorowali wybrane aspekty biografii. Przywoływany wyżej Lewin wytykał swoim poprzednikom nadużycia, nadinterpretacje i krytykował "wyssane z palca” rewelacje, podnoszone do statusu ważkich uzupełnień lub odkryć4 . Wysoko oceniał jedynie książki autorów, którzy Korczaka znali osobiście, czyli zbiory wspomnień Idy Merżan oraz dwie pierwsze opowieści biograficzne syntetyzujące życiorys i dokonania Starego Doktora - wielokrotnie wznawianą i tłumaczoną publikację Hanny MortkowiczOlczakowej Janusz Korczak oraz Igora Newerlego Żywe wiqzanie. Były to w jego opinii „książki-matki, które wydały na świat liczne potomstwo”. Napisane przez bliskich współpracowników Doktora, oparte na ich osobistych wspomnieniach, zdaniem Lewina „tworzą jakiś kanon, fundament bardzo użytecznej wiedzy”.

Problem w tym, że wspomnieniowo-literacka wizja rzeczywistości - zarysowana w docenionych przez Lewina pozycjach - traktowana była często bezkrytycznie jako podstawa źródłowa i utrwalała w zbiorowej pamięci informacje niepewne, skąpe, subiektywne. Świadomy tego autor Korczaka znanego i nieznanego postulował potrzebę „biografii naukowej, opartej na dokładnej znajomości wszelkich dostępnych źródeł: bezpośrednich i pośrednich, mało dotąd znanych lub w ogóle nieznanych"7. Jego książka jest próbą rzetelnej rekapitulacji faktów oraz wskazania kierunków poszukiwań, które należy podjąć, aby wyjść z zaklętego kręgu, nakreślonego w dotychczasowych interpretacjach.

Publikacja ta nie przebiła się jednak do szerszego kręgu odbiorców. Zignorowała ją także ostatnia biografka Korczaka, Joanna Olczak-Ronikier ${ }^{8}$. To jej Próba biografi wydana w 20II roku stanowi dla współczesnego czytelnika kompendium wiedzy o Januszu Korczaku9 . Wznawiana i tłumaczona, wyróżniona dwiema prestiżowymi nagrodami (w tym Klio, przyznaną przez Porozumienie Wydawców Książki Historycznej) - kształtuje dziś wizerunek Starego Doktora. Z jej licznych recenzji przebija entuzjazm, że wreszcie ktoś rozprawił się z legendą, że pomnik

4 Jak na przykład historie związane z chorobą ojca Korczaka czy domniemane zdrady małżeńskie w tej rodzinie. Zob. A. Lewin, Korczak znany i nieznany, s. 65-66.

5 Ibidem, s. 411.

6 Ibidem, s. 407.

7 Ibidem, s. 412.

8 Świadczy o tym nie tylko brak odwołań do książki Korczak znany i nieznany, ale też powielanie przez autorkę ,informacji” zdementowanych przez Lewina, np. dotyczących stosunków rodzinnych Goldszmitów.

9 Zob. J. Olczak-Ronikier, Korczak. Próba biografii, Warszawa 2011, wyd. nast. 2012. 
został odbrązowiony. Tytuły Korczak odczytany na nowo ${ }^{\text {IO }}$ czy Biografia spetniona ${ }^{\text {II }}$ zapowiadają przełom w spetryfikowanym obrazie „króla dzieci”. I rzeczywiście curriculum vitae zaproponowane przez Olczak-Ronikier jest inne od tych znanych z wcześniejszych ujęć. Opracowanie opatrzone indeksem i przypisami robi wrażenie dobrze udokumentowanej pracy. Czy jednak istotnie lektura tej książki sprawia, że nasza wiedza o Henryku Goldszmicie jest dziś mniej „fragmentaryczna i powierzchowna" niż dwadzieścia lat temu?

Prowadzone przeze mnie od kilku lat badania dokumentacyjne zogniskowane wokół genealogii Korczaka prowadzą do wniosku, że wiele pozostaje jeszcze do odkrycia. Przez skonfrontowanie początkowych fragmentów Próby biografii z dostępnymi źródłami postaram się wykazać, jak kwerendy archiwalne i powrót do filologicznego namysłu nad tekstem mogą zdezawuować niepodważalne, zdawałoby się, tezy oraz poszerzyć spektrum badań biograficznych nad tą postacią.

„Olczak-Ronikier obficie cytuje źródła: od dokumentów urzędowych do tekstów literackich. To bezsprzecznie jedna z największych zalet obranej przez nią metody" czytamy w jednej z recenzji Próby biografi ${ }^{\text {i2 }}$. Sama autorka stwierdza, że jej narracja

\} \text { próbuje dotrzeć do podziemnych źródeł, do korzeni. Może podróż } w tamte odległe czasy, kiedy żyli jego przodkowie, kiedy się rodził, kiedy był chłopcem, kiedy dorastał do swojego powołania i kiedy je wypełniał, przywoła choćby cień Starego Doktora $[\ldots]^{13}$.

Założenia te są dodatkowo wzmocnione fragmentem z gettowego Pamiętnika Korczaka, świadczącym o jego niezrealizowanym planie napisania autobiografii opartej na zamyśle, „by dotrzeć do siebie, poszukując dziedzictwa otrzymanego od kolejnych pokoleń” ${ }^{4}$. Zgadzam się w pełni z tezą, że Korczak miał głęboką świadomość tego, ile zawdzięcza swoim przodkom. Twierdził nawet, że ważniejsze od poznawczych walorów autobiografii i życiorysów są badania genealogiczne. $W$ jego wstępie do broszury Jędrzeja Śniadeckiego znajdziemy passus:

\section{\Z Z autobiografii zasłużonych i wielkich poznajemy ich niejako, z ży- ciorysów zgadujemy pracowicie, najczęściej zgadujemy błędnie. [...]}

10 A.M. Kola, Korczak odczytany na nowo, „Praca Socjalna” 2012, nr 2.

11 A. Witkowska, Biografia spetniona, „Cwisz[y]n” 2011, nr 4.

12 E. Szybowicz, Zapomnij o świętym Korczaku, https://www.dwutygodnik.com/artykul/2321-zapomnij-o-swietym-korczaku.html (stan z 29 września 2020 r.).

13 J. Olczak-Ronikier, Korczak. Próba biografii, s. 12.

14 Ibidem. 
Ile jednak ważniejsze [jest - M. S.] zagadnienie ich rodu! Herby i konie wyścigowe mają genealogie, nie mają jej uczeni [...]. Niechby wiedziano, ile pokoleń zbiera mozolnie soki w ciszy i cieniu, zanim do słońca wychyli się - kwiat rodu ${ }^{\mathrm{I5}}$.

Wcześniejsze biografie Korczaka nie zgłębiają tematu jego genealogii. Pokutuje przekonanie wyrażone w jednej z „książek-matek”: „Metryki i akty zejścia spłonęły

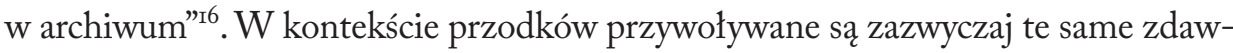
kowe informacje pochodzące z pamiętnikarskich zapisków Korczaka: o pradziadku, który był szklarzem, i dziadku Herszu Goldszmicie. Dopiero w ostatniej Próbie biografi - zgodnie z zapowiedzią autorki o „docieraniu do korzeni”- znajdziemy kilka rozdziałów poświęconych rodzinie Starego Doktora.

I tak, w pierwszym z nich przeczytamy sugestywny opis dziejów typowego żydowskiego rzemieślnika żyjącego pod koniec XVIII wieku w małym miasteczku. Tajemniczemu dotąd pradziadowi szklarzowi nadaje Ronikier hipotetyczne imię, Eliezer Chaim, oraz datę urodzenia („dla jasności opowieści” zakłada, że był on rówieśnikiem hrubieszowskiego wynalazcy, Abrahama Sterna). Następnie sięgając do opowiadania Korczaka zatytułowanego Trzy wyprawy Herszka, sugeruje, że „znalazł żonę w tym samym środowisku małomiasteczkowej biedoty, z którego się wywodził, i spłodził z nią syna o imieniu Lejb. [...] w roku i8o5 urodził mu się kolejny syn - Hersz" ${ }^{\text {17 }}$. Dalsze karty rozdziału zapełnia streszczenie historii tegoż Hersza... czteroletniego bohatera literackiego, który postanawia przeprowadzić Żydów z małego miasteczka do Palestyny ${ }^{\mathrm{I} 8}$. „Czy Korczak opowiadał o swoim dziadku?” - pyta Ronikier retorycznie. W końcu stwierdza rzeczowo: „Nie odtworzy się już drogi Hersza. Można ją sobie wyobrazić dzięki innym przekazom”' ${ }^{\prime 9}$.

Dla przybliżenia czytelnikowi, jak mogły wyglądać losy Hersza Goldszmita, autorka przywołuje autentyczne historie szwagra swojej babki, Zygmunta Bychowskiego, oraz pradziadka Antoniego Słonimskiego, wspomnianego wyżej Abrahama Sterna ${ }^{20}$. Wobec braku dostępu do autentycznych źródeł na temat

15 J. Korczak, Stowo wstępne [do rozprawy Jędrzeja Śniadeckiego] „O fizycznym wychowaniu dzieci”, Warszawa 1920, przedruk w: idem, Dzieta, t. 13, Warszawa 2016, s. 13.

16 H. Mortkowicz-Olczakowa, Janusz Korczak, s. 23.

17 J. Olczak-Ronikier, Korczak. Próba biografi, s. 19-20.

18 Zob. J. Korczak, Trzy wyprawy Herszka, Warszawa 1939, przedruk w: idem, Dzieta, t. 12, Warszawa 1998. Dobrze udokumentowana geneza powstania tego utworu plasuje go wśród tzw. opowieści palestyńskich, czyli utworów powstałych pod bezpośrednim wpływem doświadczeń i przeżyć Korczaka podczas dwóch jego podróży do Palestyny, w 1934 i w 1936 r.

19 J. Olczak-Ronikier, Korczak. Próba biografii, s. 26.

20 Ibidem. 
protoplastów bohatera książki, autorka konstruuje ich losy, wykorzystując twórczość literacką Korczaka, autentyczne przekazy dotyczące innych osób oraz własną wyobraźnię. Narracja jest na tyle przekonująca, że w jednej z recenzji czytamy: „Ronikier [...] rekonstruuje całe życie Korczaka, począwszy od dziejów jego pradziadka, hrubieszowskiego szklarza Eliezera Chaima Goldszmita [...]”². Zwroty typu „podobno” czy „załóżmy”, którymi asekuruje się autorka, w odbiorze czytelniczym tracą swoją wagę. Artystyczna kreacja losów postaci zostaje potraktowana jako solidna „rekonstrukcja” ich dziejów. Pozostaje pytanie: czy dowiadujemy się na tej podstawie czegoś nowego o przodkach Janusza Korczaka?

Koleje antenatów po mieczu są konstrukcją artystyczną, a protoplaści po kądzieli właściwie nie istnieją w tej biografii. Zważywszy na matrylinearny system pokrewieństwa w kulturze judaistycznej, pominięcie to może dziwić, zwłaszcza że Ronikier - w przeciwieństwie do poprzedników zgodnych co do głębokiego zasymilowania rodziny, z której pochodził autor Kajtusia czarodzieja - wielokrotnie wyraźnie podkreśla przede wszystkim żydowską tożsamość Korczaka. W Pamiętniku pisanym w ostatnich miesiącach życia znajdziemy wyznanie pisarza dotyczące rodziców: „Jestem i matką, i ojcem. Wiem i wiele dzięki temu rozumiem”22. W innym miejscu przeczytamy:

\section{\Matuś - Ojczulku. [...] ze wszystkich skamieniałych tęsknot i bólów Waszych i moich przodków pragnę wznieść wysoką, strzelistą, samot- ną wieżę dla ludzi. [...] Liczba tych pod ziemią szkieletów [...] jest tylko za ostatnich lat trzysta - aż tysiąc - i dwadzieścia - i cztery. Jak różne nosili imiona ${ }^{23}$.}

Mojżesz, Sender, Izrael, Fogela, Natan, Zysla... To jedynie niektóre z nich. Odczytane z jednego wyłącznie, sporządzonego w języku polskim w Kaliszu w I82I roku, aktu ślubu pradziadków Henryka ze strony matki - Szymona Dejczera i Cyrli Wolf (to po niej matka Korczaka otrzymała imię, tyle że w spolszczonej wersji Cecylia). Wiele innych metryk zachowało się w archiwach w Poznaniu, Lublinie, a także w Warszawie. Odtworzone drzewo genealogiczne ze wszystkimi danymi, jakie udało mi się ustalić, zamieściłam na platformie Nowa Panorama Literatury Polskiej ${ }^{24}$. Wbrew przekonaniom powielanym przez lata o braku archiwaliów historię obu rodów można próbować rekonstruować na podstawie materiałów

21 A. Bikont, Korczak, „Zeszyty Literackie” 2011, nr 3, s. 226.

22 J. Korczak, Pamiętnik i inne pisma z getta, Warszawa 2012, s. 122.

23 Idem, Dedykacja, w: idem, Sam na sam z Bogiem, Warszawa 1922, s. 69-70.

24 Zob. https://nplp.pl/artykul/drzewo-genealogiczne-osoby/ (stan z 23 października 2020 r.). 
źródłowych. $Z$ metryk urodzenia, śmierci i ślubu poszczególnych członków rodziny da się wyczytać nie tylko nazwiska i daty. Na przykład ze wspomnianego wyżej aktu dowiadujemy się między innymi, że pradziadek Korczaka, „krawiec z Kalisza”, był synem „Izraela i Fogeli z Moyzeszów małżonków Deytscherów handlarzy w Ostrowie mieszkających”, a jego prababka Cyrla przybyła na swój ślub „w asystencji tylko ojca swego Natana Wolf rzezaka z Kalisza, gdyż matka jej [...] Zyska ze Zandrów w dniu szóstym października tysiąc ośmset czwartego roku z tym się rozstała światem" ${ }^{25}$. Z tego samego aktu wynika, że Cyrla miała brata Józefa Wolfa, kramarza, a oboje młodzi byli związani rodzinnie z Brokmanami - świadkami ślubu byli między innymi wuj Szymona, sześćdziesięcioośmioletni Mojżesz Brokman, skórnik, a także brat cioteczny Cyrli, rybak Abraham Brokman. Co ciekawe, we wskazanym dokumencie jedyny (prócz parafki urzędnika) autograf w języku polskim to podpis: „Simon Deiczer”. Reszta obecnych zobowiązanych do podpisu złożyła go w jidysz, „wyjąwszy pannę młodą, która pisać nie umie”26.

Historia niepiśmiennej prababki, żony krawca, który w I82I roku pisze swoje nazwisko bardziej po polsku niż ówcześni polscy urzędnicy (w różnych aktach między innymi: Deutscher, Dajtscher, Daytzer), inspiruje do zbadania pierwszych śladów integracji tej żydowskiej rodziny z polskością, szczególnie że to w akcie zgonu Cyrli z 1845 roku natkniemy się po raz pierwszy na spolszczenia żydowskich imion osieroconych córek: Zuzanny (zamiast metrykalnego Sisse) oraz Ernestyny (zamiast Estery) ${ }^{27}$. Nazywanie dzieci polsko brzmiącymi imionami z całą pewnością można odczytywać jako świadomy gest asymilacji. Ukochana babcia Korczaka, Emilia, w akcie urodzenia figuruje jeszcze jako Mina (a nie Mila, jak błędnie podaje Ronikier). Dopiero po ślubie z Józefem Adolfem Gębickim (synem Maurycego i Anny Rozalii) zaczyna w metrykach urodzenia ich dzieci pojawiać się spolszczona (czy chrześcijańska) postać jej pierwotnego imienia. $Z$ pobieżnego nawet oglądu wspomnianego drzewa genealogicznego wynika jasno, że to w rodzinie Gębickich proces asymilacji przebiegał wcześniej niż u Goldszmitów. Zgłębienie tego tematu mogłoby przynieść nowe spojrzenie na zagadnienie podwójnej, żydowsko-polskiej tożsamości Janusza Korczaka.

Innym wątkiem wymagającym pogłębionych badań jest boczna gałąź drzewa, zapoczątkowana przez wzmiankowaną już Esterę (Ernestynę) Dejczer - starszą siostrę babki Emilii. Odnaleziony niedawno list Henryka Goldszmita do jej syna, znamienitego otolaryngologa Ludwika Guranowskiego, rzuca nowe światło na

25 Zyska ze Zandrów to najpewniej Zisl córka Sendra, forma jej imienia została przy rejestracji zniekształcona przez urzędnika.

26 Akt nr 11; oryginał dostępny w Archiwum Państwowym w Poznaniu (mikrofilm 743142).

27 Akt nr 56; oryginał dostępny w Archiwum Państwowym w Poznaniu (mikrofilm 743144). 


\section{W.}

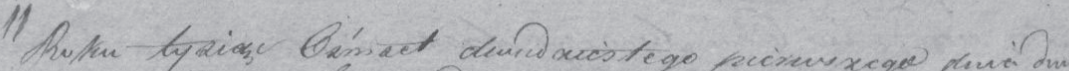

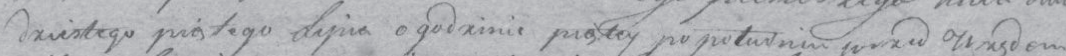

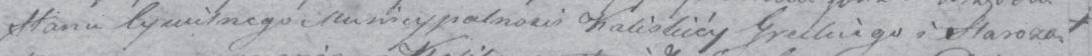

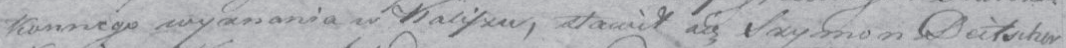

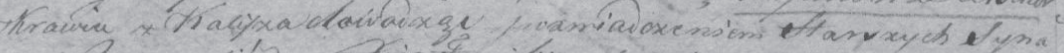

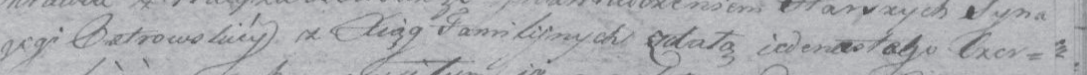

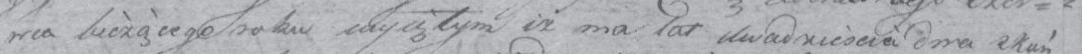

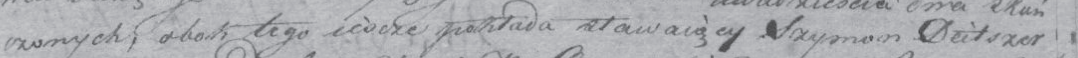

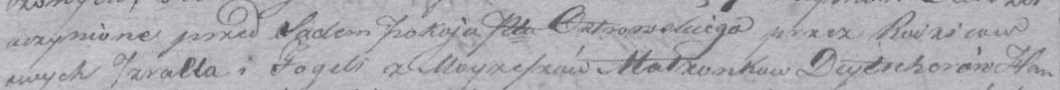

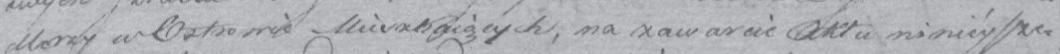

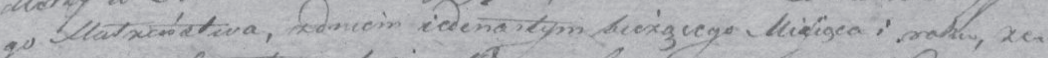

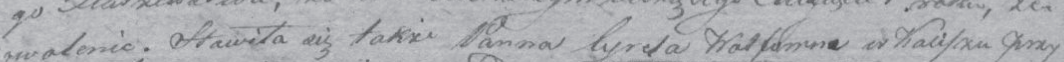

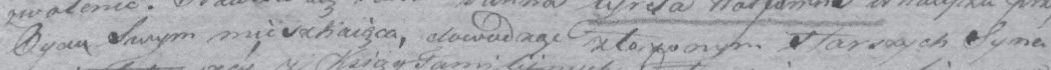

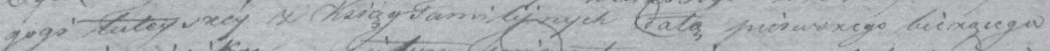

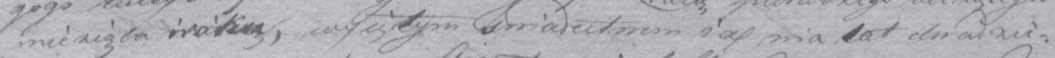

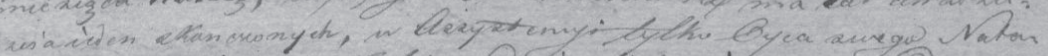

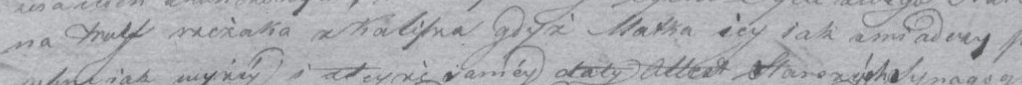

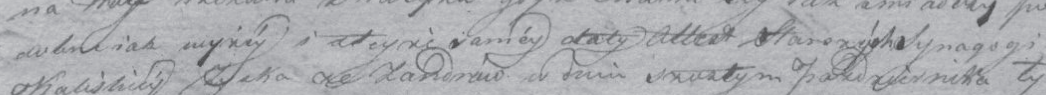

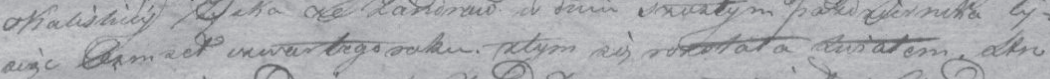

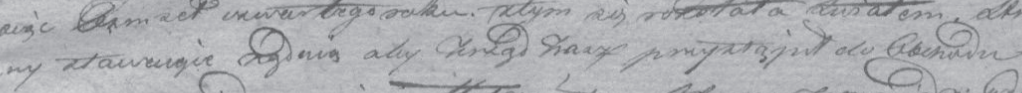

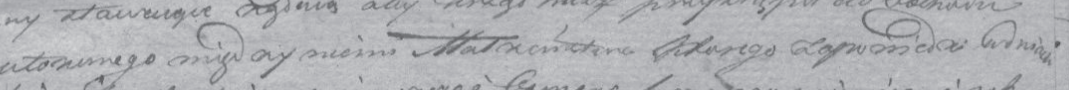

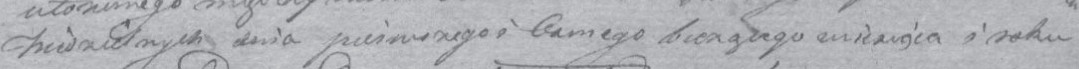

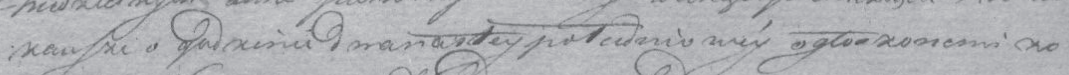

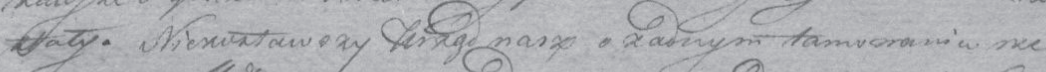

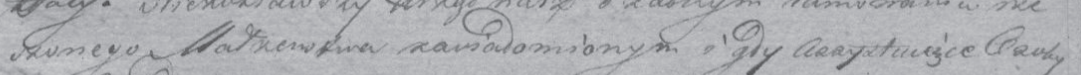

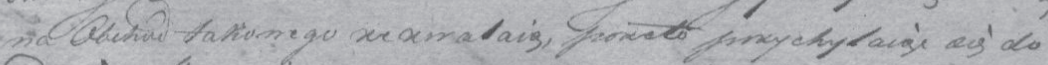

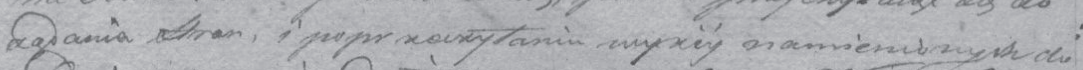

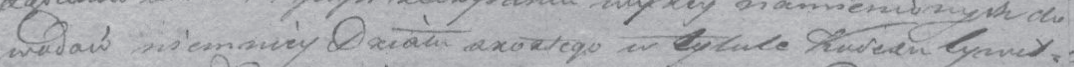

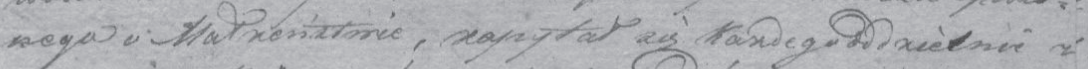

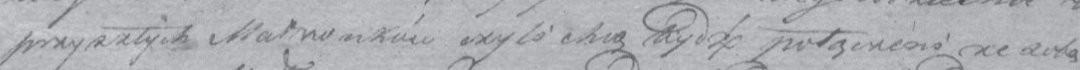

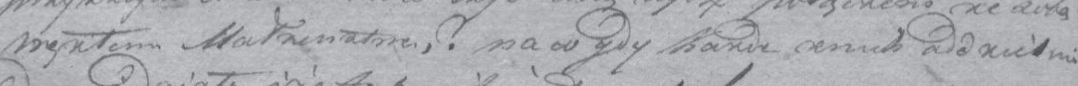

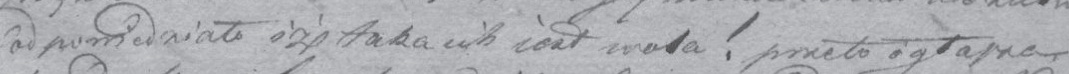

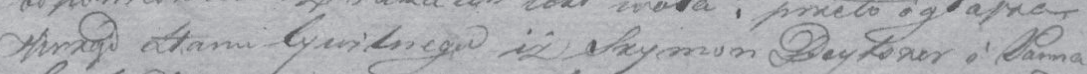

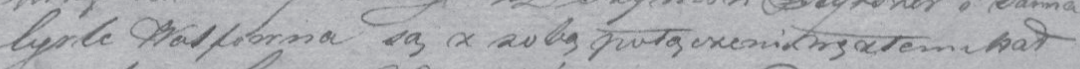

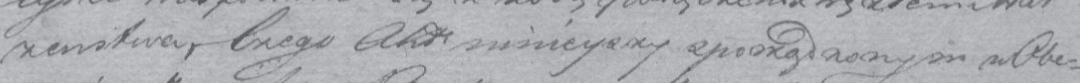

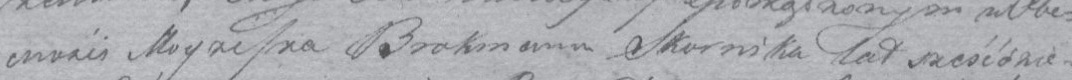

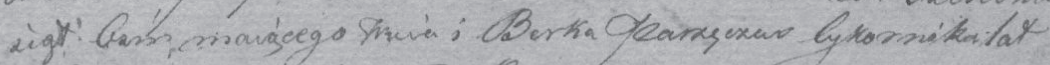

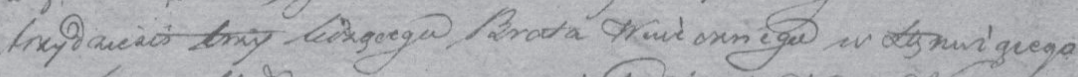

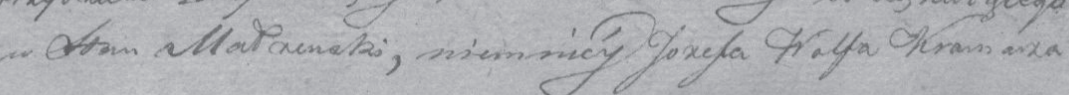

$$
0.7 \text {. Y Ma }
$$




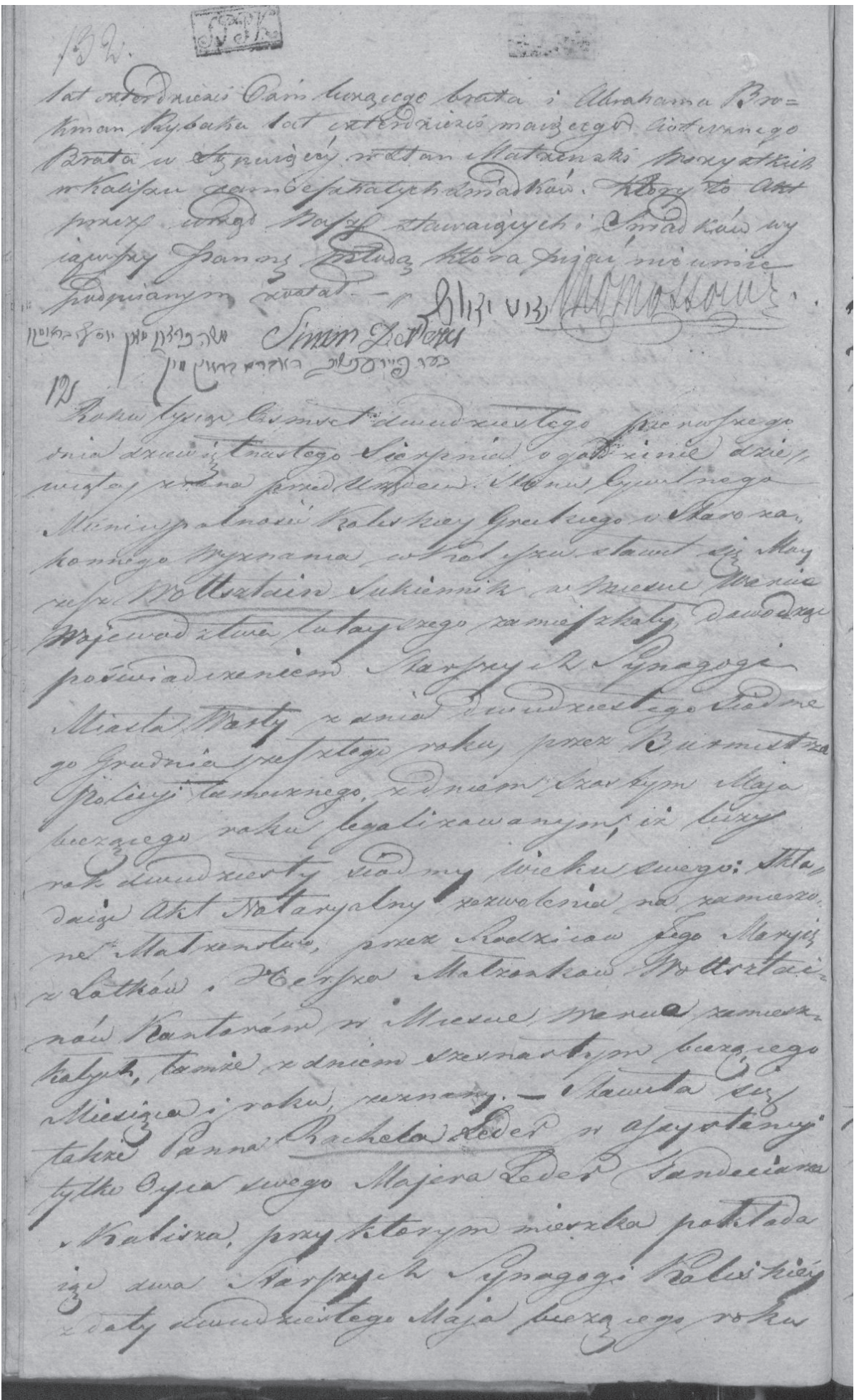


stosunki Korczaka z rodziną matki ${ }^{28}$. Nagłówek „Kochany Wujaszku” czy pożegnalny zwrot „Pozdrowienia dla Domu” świadczą o zażyłości tych kontaktów. Pokrewieństwo autora Dzieci ulicy z dość znanymi w Młodej Polsce pisarzami Mieczysławem i Jerzym Guranowskimi to dla badaczy wciąż teren dziewiczy. Jego rozpoznanie pomoże zweryfikować utrwalone w publikacjach biograficznych przekonanie, że to Goldszmitowie byli Henrykowi bliżsi. To, że Korczak dwukrotnie wspomina bezimiennego pradziadka szklarza, nie umniejsza faktu, że inny jego pradziad, Maurycy Gębicki, urodzony w I780 roku w Piotrkowie Trybunalskim, „był znanym z uczciwości i rozległej nauki i praktyki lekarzem”29, chirurgiem. Dziadka Józefa, kupca i działacza społecznego z Kalisza, także nie przywołuje na kartach swoich wspomnień, ale źródła mówią o nim całkiem sporo ${ }^{30}$. Tymczasem w zbiorowej świadomości utrwala się obraz nakreślony w artystycznej wizji:

\Widzimy pradziadka Korczaka, sierotę z Hrubieszowa, jak opuszczony przez wszystkich siedzi na progu zapadłej chaty. I ten chłopiec zdołał się wyrwać ze wsi i zostać lekarzem. Ta postać była niesłychanie ważna dla Korczaka. Wyznaczyła wręcz linię jego życia ${ }^{3 \mathrm{I}}$.

Postać literacka, Herszek z opowiadania Korczaka, kształtuje wyobraźnię czytelników na temat stosunków rodzinnych Goldszmitów ${ }^{32}$. Wydaje się jednak, że uzupełnianie luk biograficznych hipotezami ma sens wtedy, gdy hipotezy uwzględniają wszelkie dostępne informacje. Jeśli zaś pomijają część źródeł, wówczas nie przyczyniają się do wytyczenia granicy między legendą a faktografią, a jedynie dobudowują do legendy kolejne elementy.

W Próbie biografii znajdziemy jeszcze jeden, od lat eksploatowany cytat z Pamiętnika Korczaka, dotyczący jego przodków:

\section{》 Nazywam się po dziadku, a imię dziadka Hersz (Hirsz). Ojciec miał prawo nazwać mnie Henrykiem, bo sam otrzymał imię Józef. Także}

28 Odkrycia dokonała prawnuczka Guranowskiego, Anna Poczobut. List znajduje się wśród materiatów do Stownika Lekarzy Polskich Ludwika Guranowskiego, zdeponowanych w Oddziale Rękopisów Biblioteki Jagiellońskiej.

29 Z.P., Wspomnienie pośmiertne, „Izraelita” 1877, $\mathrm{nr} 23$.

30 Zob.ibidem:„Ogólne zaufanie współobywateli, przemysłowców, obywateli wiejskich, przedstawicieli władz krajowych, czyniło ze zmarłego Gębickiego osobistość tak popularną w Kaliszu, że bez najmniejszej przesady rzec można, iż żadna ważniejsza miejscowa kwestia obcą mu nie była, że żadna instytucja, bez względu na jej charakter publicznej działalności, nie obyła się bez czynnego współudziału Gębickiego".

31 J. Sobolewska, Za murem, „Polityka” 2011, nr 24.

32 Recenzentka ma zapewne na myśli dziadka Hersza Goldszmita, a nie pradziadka. 
pozostałym dzieciom nadał dziadek imiona chrześcijańskie: Maria, Magdalena, Ludwik, Jakub, Karol ${ }^{33}$.

Sprostujmy dla porządku dwie nieścisłości. Karol był bratem matki Korczaka, Cecylii z Gębickich ${ }^{34}$. Dziadek Hersz nadawał natomiast swoim dzieciom imiona raczej w tradycyjnej żydowskiej formie ${ }^{35}$. Również ich dane osobowe udało mi się potwierdzić dzięki kwerendom w archiwach ${ }^{36}$. Korczak się tutaj myli. Może zatem także błędnie zakłada, że sam otrzymał imię chrześcijańskie? Chyba tym tropem poszła Joanna Olczak-Ronikier.

W Próbie biografii znajdziemy więc historię związaną ze spóźnioną rejestracją urodzin syna w odpowiednim urzędzie przez szacownego adwokata, Józefa Goldszmita. Autorka przypomina, że ojciec nie dopełnił swojego obowiązku w terminie, i szuka powodu takiego zaniedbania. Dochodzi do wniosku, że Józef Goldszmit rozpięty między dwoma światami polskim i żydowskim nie może się długo zdecydować, jaką tożsamość zafundować synowi.

\section{》W końcu podjął decyzję. Postąpił na przekór zdrowemu rozsądkowi, za to w zgodzie $\mathrm{z}$ własnymi przekonaniami. Jego syn otrzymał urzę- dowe imię Hirsz i został zarejestrowany w „kancellaryi dla wyznań niechrześcijańskich”37.}

Fragment ten podważa nie tylko świadectwo samego Korczaka, ale i sądy dotychczasowych biografów i badaczy jego twórczości. Sugeruje rewelacyjne odkrycie dawno zaginionej metryki urodzenia Starego Doktora. Czytelnik nie spodziewa się, że autor biografii mógłby bezpodstawnie zmienić imię jej bohatera. Jedynie kwerendy źródłowe mogą tę kwestię rozstrzygnąć. Tropu w poszukiwaniach dostarcza dziennik Korczaka:

33 J. Korczak, Pamiętnik i inne pisma z getta, s. 122.

34 Ostatnia biografka pisze, że „nic o nim nie wiadomo” (J. Olczak-Ronikier, Korczak. Próba biografii, s. 30), mimo że już w 1989 r. jego dane na podstawie odnalezionej metryki urodzenia opublikowała Maria Falkowska, zob. eadem, Kalendarz życia, dziatalności i twórczości Janusza Korczaka, Warszawa 1989, s. 34. Poczynione przeze mnie kwerendy przyniosły wiele nowych informacji o tej postaci. Zob.: http://nplp.pl/artykul/karol-gebicki/ (stan z 23 października 2020 r.).

35 A więc Lejzor, Mindla, Mariem, Josef, Jacob (w jednym dokumencie Jankiel). Tylko jego najmłodszy syn z drugiego małżeństwa z Surą Esterą Wajngarnt ma w metryce imię Aleksander Sender. Zob. http://nplp.pl/artykul/aleksander-sender-goldszmit/ (stan z 23 października 2020 r.).

36 Zebrany przeze mnie materiał źródłowy przeczy tezie postawionej przez Ronikier, jakoby „wpisywanie dziewczynek do ksiąg metrykalnych w tamtych czasach wydawało się niepotrzebnym zawracaniem głowy" (J. Olczak-Ronikier, Korczak. Próba biografii, s. 30). Z badań wynika, że rejestrowano dzieci bez względu na płeć, nawet te, które urodziły się martwe i którym nie nadawano imion.

37 Ibidem, s. 47. 
\Jutro kończę sześćdziesiąt trzy albo sześćdziesiąt cztery lata. Ojciec przez parę lat nie wyrabiał mi metryki. Przeżyłem z tego powodu kilka ciężkich chwil. - Mama nazywała to karygodnym niedbalstwem: jako adwokat powinien był ojciec sprawy metryki nie odwlekać (zapis z 2I lipca 1942$)^{38}$.

A więc zaginionego aktu należało szukać nie w roku domniemanego urodzenia pisarza (1878 lub i879), lecz kilka lat później. Podążając za wskazówką z diariusza, w Warszawskim Archiwum Państwowym odszukałam wtóropis księgi metrykalnej, w której został zarejestrowany syn Józefa Goldszmita. Wprawdzie brakuje w nim karty z rzeczoną metryką, ale z zamieszczonego na końcu skorowidza jasno wynika, że w lipcu I88I roku po przeprowadzce rodziny na Krakowskie Przedmieście (cyrku1 I/XI) został zarejestrowany Henryk Goldszmit (ГольАшмить Генрикъ). Numer aktu (88) i imię Henryk potwierdzają się także w dotyczących służby wojskowej Korczaka dokumentach personalnych, analizowanych przez Kingę Sienkiewicz ${ }^{39}$.

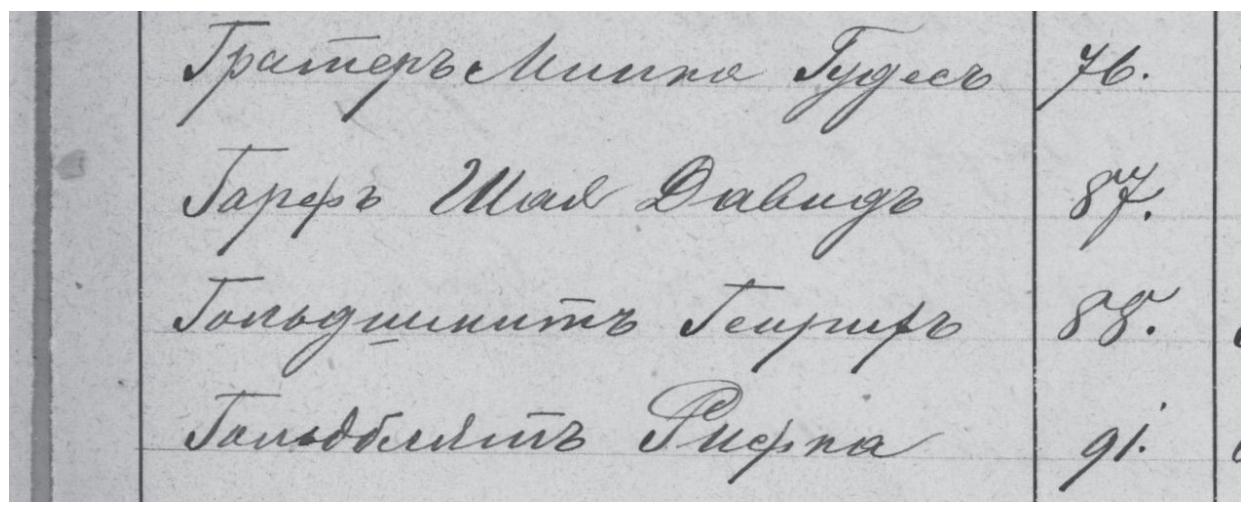

2. Fragment skorowidza księgi aktów stanu cywilnego z 1881 r.

Toteż nie ma wątpliwości: otrzymał chrześcijańskie imię, choć rzeczywiście po dziadku Herszu (zgodnie z tradycją żydowską), tak jak i siostra Anna po babce Chanie Goldszmit ${ }^{40}$. To sprawa niebagatelna. Henryk i Anna byli pierwszym pokoleniem w rodzinie Goldszmitów, które w metrykach urodzenia miało nieżydowskie imiona.

38 J. Korczak, Pamiętnik i inne pisma z getta, s. 122.

39 Szerzej pisałam o tym w artykule Uwolnic Korczaka? Zagadnienie praw autorskich do spuścizny autora „Króla Maciusia Pierwszego", w: Literatura w granicach prawa (XIX-XX w.), red. K. Budrowska, E. Dąbrowicz i M. Lul, Warszawa 2013.

40 Jej akt urodzenia także udało mi się odnaleźć. Zob.: http://nplp.pl/artykul/anna-goldszmit/ (stan z 23 października 2020 r.). 
Okazuje się zatem, że passus dotyczący rejestracji w „kancellaryi” jest wplecionym zręcznie w odautorską narrację cytatem $\mathrm{z}$ innego dokumentu, który ma uwiarygodnić opowieść. Ale to jedynie zabieg stylistyczny. O tym, jak bardzo przekonujący, świadczy chociażby fragment okolicznościowego artykułu na temat Starego Doktora, dwukrotnie publikowanego na łamach „Rzeczpospolitej”:

\section{\Joanna Olczak-Ronikier w książce Korczak. Próba biografii twierdzi, że ojciec nie był pewien, czy pójść za głosem serca czy rozsądku, w jaki los wpisać syna - Żyda czy Polaka. Ostatecznie jednak dziecko uznanego adwokata zostało zarejestrowane w „kancellaryi dla wyznań niechrześcijańskich”. Otrzymało imię Hirsch ${ }^{4 \mathrm{I}}$.}

W najnowszym przedstawieniu teatralnym opartym na biografii Korczaka ${ }^{42}$ pada zdanie: „Mam na imię Hersz”, i to również jest powielane w recenzjach: „Aby być precyzyjnym, należy powiedzieć, że bohaterem spektaklu Spowiedź motyla w warszawskim Teatrze Ateneum jest czternastoletni Hersz Goldszmit” - przeczytamy $\mathrm{w}$ jednej $\mathrm{z}$ nich ${ }^{43}$.

„Informacja” podana przez Ronikier zaczyna żyć własnym życiem w środkach masowego przekazu oraz w kulturze. Na stronach znanego portalu culture.pl, w artykule zatytułowanym wymownie $I 2$ rzeczy o Korczaku, które warto wiedzieć punkt drugi wyliczanki brzmi:

\ Człowiek, którego rok obchodziliśmy w 2012 roku w Polsce, naprawdę nazywał się Henryk Goldszmit, a w zasadzie Hersz Goldszmit, bo takie imię syn Cecylii z d. Gębickiej i Józefa Goldszmita otrzymał $\mathrm{w}$ urzędzie. Było to zgodne z żydowską tradycją nakazującą, żeby chłopiec otrzymał imię po dziadku. W następnych latach przyjęło się, że Hersz było imieniem odświętnym, a na co dzień używano imienia Henryk. Z perspektywy czasu wydaje się, że wybór imienia miał głębsze symboliczne znaczenie: Korczak poszedł w ślady dziadka, który w Hrubieszowie działał jako lekarz, założył tam też Szpital Starozakonnych. Przede wszystkim jednak wybór imienia

41 K. Wołodźko, Korczak. Życiorys niesentymentalny, „Rzeczpospolita” 2014, dod. „Plus Minus” nr 29 oraz ibidem 2017, https://www.rp.pl/Plus-Minus/307189987-Korczak-zyciorys-niesentymentalny. html (stan z 23 października 2020 r.).

42 Zob. Spowiedź motyla, reż.J. Kijowska, W. Faruga. Premiera: Warszawa, Teatr Ateneum, 5 października 2017 r.

43 Zob. K. Łapicka, O czym śni motyle, http://zteatru.p1/2017/11/15/ateneum/ (stan z 23 października 2020 r.). 
i zarejestrowanie go w „kancelaryi dla wyznań niechrześcijańskich” równoznaczny był $\mathrm{z}$ wyborem narodowej tożsamości, z perspektywy historii miał się okazać wyborem tragicznym ${ }^{44}$.

Obraz nakreślony z niezwykłą sugestywnością modeluje wyobraźnię odbiorców. Po Próbę biografii sięgną przecież także (a może zwłaszcza) ci, „którzy interesują się Korczakiem i chcieliby o nim jak najwięcej wiedzieć”. Historia opowiedziana przez Ronikier wydaje się spójna i przekonująca. Zmiana imienia głównego bohatera z Henryk na Hersz nie jest przypadkowa, precyzyjnie wpisuje się w inne twierdzenie autorki: „Ojciec Korczaka nie był tak zainfekowany bakcylem polskości jak moja prababka" ${ }^{5}$. To pod tę tezę została poprowadzona narracja dotycząca rejestracji chłopca w urzędzie. Brak metryki implikuje przestrzeń domysłów i subiektywnych założeń, ale krytyka źródeł sprowadza nas z powrotem na grunt twardych faktów.

Postać ojca Korczaka wymaga zresztą osobnego omówienia. Ujęcie Ronikier opiera się na wcześniejszych sugestiach wyrażonych w „książkach-matkach”, cytowanych wielokrotnie na kartach jej pracy. Autorka Próby biografii idzie jednak znacznie dalej niż jej poprzednicy. Uzupełnia wizerunek Józefa Goldszmita na podstawie utworów literackich jego syna oraz własnej fantazji. Spróbuję pokazać, co z tego wynika dla naszej wiedzy o Starym Doktorze.

Lektura pierwszej biografii książkowej zatytułowanej Janusz Korczak przynosi dość niejednorodny obraz ojca. W rozdziale Rodowód czytamy, że „Józef Goldszmit był znanym i cenionym adwokatem w Warszawie, autorem dzieła o prawie rozwodowym" ${ }^{6}$, ale już w następnym (pod tytułem Smutne dzieciństwo) Hanna Mortkowicz-Olczakowa dodaje, że ,zarabiał dużo, lubił wystawne życie i zbytek, uosabiał fantazję i rozmach życia”. Znajdujemy ponadto informację, że był „wspaniałym, pełnym inicjatywy ojcem”, ,nieobliczalny, ukochany...”. Tym tragiczniejsza miała być w tych okolicznościach „katastrofa, która nadeszła, kiedy Henio miał jedenaście lat. Choroba - obłęd ojca”. Dalej miało być „lekkomyślne wyprzedawanie przez ojca wszystkich cennych rzeczy, bankructwo, potem ogromne koszty związane z jego leczeniem. Utrata domu, mebli przez licytację, wszystkie zwyczajowe i ponure okoliczności materialnej katastrofy, które rozprzęgły dotychczasowe życie"47. Do tego obrazu swoje dodaje Igor Newerly w Żywym wiq̨zaniu:

44 M. Gliński, 12 rzeczyo Korczaku, które warto wiedzieć, https://culture.pl/pl/artykul/12-rzeczy-o-korczaku-ktore-warto-wiedziec ( $\operatorname{stan}$ z 23 października 2020 r.).

45 J. Olczak-Ronikier, Korczak. Próba biografii, s. 45.

46 H. Mortkowicz-Olczakowa, Janusz Korczak, s. 22.

47 Ibidem, s. 27-28. 
》Józef Goldszmit, adwokat na pełnym nurcie powodzenia, nie bez aspiracji naukowych, autor cenionej ponoć rozprawy o postępowaniu rozwodowym, koneser życia i dowcipu, jako ojciec nieco roztargniony, ale koleżeński, może nazbyt koleżeński; jako mąż pomimo całej miłości i czci, nie zawsze wzorowy ${ }^{48}$.

Twórczo rozwija te sugestie autorka ostatniej biografii Starego Doktora. Przeplatanie ekspresyjnej narracji własnej wybranymi fragmentami powieści Dziecko salonu na przemian z wyimkami z Pamiętnika powoduje, że plastyczny, wyrazisty obraz jego ojca zapada głęboko w pamięć. Józef Goldszmit widziany z perspektywy Próby biografii to „Światowiec [...], zamożny, elegancki, wykształcony, lubił uroki świata, dobre restauracje, piękne kobiety". Z synem wymykali się na Saską Kępę, gdzie spotykali „niby przypadkiem - jakąś panią. Wtedy zostawiał chłopca pod opieką miejscowego piekarza, a sam szedł na spacer z tą panią, o czym mamie nie należało mówić” ${ }^{49}$.

I dalej:

\Mecenas Goldszmit już wcześniej prowadził zbyt wystawny jak na jego możliwości tryb życia, robił nieprzemyślane inwestycje, zaciągał długi. [...] Stracił klientów, musiał zamknąć kancelarię, nie miał środków na przyjemności, do których przywykł, więc wynosił z domu i wyprzedawał za grosze cenne rzeczy. [...] Nasilały się jego dziwactwa, drażliwość, nieobliczalność. Z czasem ataki nieopanowanej furii stały się nie do zniesienia ${ }^{50}$.

Takich udramatyzowanych opisów życia rodzinnego Goldszmitów jest na kartach Próby biografii więcej. Widzimy płaczącą matkę, załamującą ręce babkę, nieszczęśliwych rodziców wychowujących nieszczęśliwe dzieci: „pierwsze lata życia zapamiętał [Henryk - M. S.] jako pasmo niekończących się udręk" - pisze Ronikier ${ }^{51}$.

Opierając się na domysłach i własnej intuicji, autorka dochodzi ostatecznie do konstatacji, że „syn, kształtując swój charakter, starał się zostać antytezą ojca”, zmiennego, egoistycznego hedonisty ${ }^{52}$.

48 I. Newerly, Żywe wiazanie, s. 32.

49 J. Olczak-Ronikier, Korczak. Próba biografii, s. 61-62.

50 Ibidem, s. 64.

51 Ibidem, s. 49.

52 Ibidem, s. 74. 
Konstruując postać Józefa - prócz utworu literackiego Korczaka, stylizowanego na pamiętniki z okresu dojrzewania: Spowiedzi motyla - wielokrotnie cytuje autorka także Dziecko salonu - powieść, w której ojciec głównego bohatera-narratora, właściciel fabryki mydła, jest przykładem typowej młodopolskiej figury drobnomieszczanina. Jak przyznaje Ronikier, to portret „konformistycznego, obłudnego filistra, z którym buntowniczy syn idealista nie umie znaleźć porozumienia"53. Fragmenty wyrażające głęboki dystans narratora wobec ojca Ronikier interpretuje jako gwałtowną polemikę, w której Korczak „wyładował cały swój młodzieńczy żal, wszystkie zawiedzione uczucia, krzywdząc chyba ojca, który z oddali wydaje się postacią tragiczną" ${ }^{\prime 4}$. Z punktu widzenia badań historycznych krzywdzące wydaje się w tym przypadku raczej traktowanie fikcji artystycznej jako źródła wiedzy o realnej postaci. Instrumentalne podejście do literatury jako materiału do życiorysu pisarza nie jest niczym nowym. Najbardziej bodaj spektakularnym exemplum tego typu praktyk stała się w ostatnich latach książka Moniki Piątkowskiej Prus. Śledztwo biograficzne $e^{55}$. O wartości takiego ujęcia dla historii literatury niech świadczą miażdżące recenzje tej pozycji, napisane przez badaczy życia i twórczości Aleksandra Głowackiego ${ }^{56}$. W przypadku Dziecka salonu badacze doszukiwali się wprawdzie w tej powieści wątków autobiograficznych, ale akurat portret ojca głównego bohatera do nich nie należał.

Tez stawianych przez Ronikier w tym kontekście trudno bronić, gdy zestawi się je $\mathrm{z}$ analizą zapisków pamiętnikarskich Starego Doktora. Tak zwany Pamiętnik jest bowiem jedynym stricte autobiograficznym tekstem Korczaka. Notatki z czterech ostatnich miesięcy życia ich autora (maj-sierpień 1942) stanowią nieocenione świadectwo epoki oraz swoiste podsumowanie życia Starego Doktora. Na kilkudziesięciu kartkach wspomina Korczak ojca aż siedmiokrotnie. Ani o matce, ani o ukochanej babci Emilii, ani o Pani Stefie, ani o nikim innym nie pisze tyle razy.

Wspomnienie „papy” znajdziemy już w pierwszym kronikarskim zapisku: maj I942 rok, godzina piąta rano. Od szerokiego opisu rozkładu domu, przez opis pokoju, przechodzi autor do szczególu: rowek na palcu wyżłobiony od trzymania ołówka uświadamia mu, że przecież wygodniej byłoby pisać piórem. I od razu skojarzenie:

\section{\Nie darmo tatulo nazywał mnie w dzieciństwie gapą i cymbałem, a w burzliwych momentach nawet idiotą i osłem. Jedna tylko babcia}

53 Ibidem.

54 Ibidem.

55 M. Piątkowska, Prus. Śledztwo biograficzne, Kraków 2017.

56 Zob. np.: A. Bąbel, Przygwożdżenie wiewiórem, „Tygodnik Powszechny”2018, nr 4; A. Martuszewska, Prus zdegradowany, „Pamiętnik Literacki” 2018, z.3; W. Ratajczak, O potrzebie wierności drobiazgom... 
wierzyła w moją gwiazdę. A tak to leń, beksa, mazgaj (mówiłem już), idiota i do luftu.

Ale o tym potem.

Mieli słuszność. Po równo. Pół na pół. Babunia i papa.

Ale o tym potem ${ }^{57}$.

Zwroty „tatulo” i „papa” sugerują, że jest to ciepłe wspomnienie podszyte charakterystycznym dla Korczaka poczuciem humoru. Dwukrotnie powtórzona zapowiedź reminiscencji rodzinnych zostaje na kartach Pamiętnika częściowo spełniona.

Następne w kolejności jest obszerne przywołanie jasełek. Na kilku stronach znajdziemy szczegółowy opis ekscytującego wydarzenia widzianego z perspektywy dziecka. Występy bożonarodzeniowe w domu Goldszmitów znów przywołują w pamięci ojca, który każe „własnoręcznie wrzucać do worka dziadka nowe, srebrne dziesięciogroszówki”. „Było pięknie i strasznie, i pouczająco" ${ }^{8}$ - podsumowuje autor.

Potem wspomnienie szopki w sierocińcu, gdzie mały Henryk ponownie był z ojcem. Drobiazgowy, kilkustronicowy opis dziecięcych przeżyć komentuje Korczak następująco:

\section{\Słusznie mama niechętnie powierzała dzieci opiece ojca i słusznie dreszczem zachwytu i porywem radości witaliśmy i wspominaliśmy - siostra i ja - nawet najbardziej forsowne, męczące, nieudane i opłakane w skutkach „przyjemności”, jakie z przedziwną intuicją odnajdywał nie nazbyt zrównoważony pedagog - tatuśs ${ }^{59}$.}

I rzeczywiście zgubne bywały konsekwencje fundowanych przez ojca „przyjemności”, jak na przykład lody czy zimna woda sodowa z sokiem ananasowym w drodze powrotnej z jasełek, „żeby się ochłodzić po tym piekielnym gorącu”. Korczak pisze w kolejnym wspomnieniu:
\Ja po jasełkach tylko dwa dni gorączkowałem. [...]
Pamiętam, że zgubiłem szalik.
I pamiętam, że kiedy leżałem jeszcze w łóżku dnia trzeciego, ojciec zbliżył się do mnie, mama go surowo skarciła:
- Masz zimne ręce. Nie podchodź.

57 J. Korczak, Pamiętnik i inne pisma z getta, s. 12.

58 Ibidem, s. 39.

59 Ibidem, s. 43. 
Ojciec wychodząc z pokoju potulnie, rzucił mi porozumiewawcze spojrzenie.

Odpowiedziałem szyfrem filuternego spojrzenia coś w rodzaju:

- Dobra jest.

Sądzę, że oboje [sic!] czuliśmy, że ostatecznie nie one - mama, babcia, kucharka, siostra, służąca i panna Maria (do dzieci) - cały ten babiniec rządził, ale my, mężczyźni.

My panami domu. Ustępujemy dla świętego spokoju ${ }^{60}$.

Te intensywne emocjonalnie wspomnienia zostały zinterpretowane przez Joannę Olczak-Ronikier zgoła inaczej. Tak odczytuje obraz ojca, wyłaniający się z relacji pamiętnikarskiej, autorka Próby biografi: „A ojciec? Jest opryskliwy, pewnie drażni go tchórzliwość syna. Może chce wymusić na nim bardziej męskie zachowanie?”ri

Porozumiewawcze spojrzenia, opisane tak czule przez Korczaka, kwituje jego biografka w ten sposób:

\} \text { ta komitywa była chwiejna i nie budziła zaufania. Ojciec pobudliwy, } zmienny w nastrojach, powodował ciągłe poczucie zagrożenia. Nigdy nie było wiadomo, jak zareaguje na jakieś wydarzenie czy wykroczenie. Czy jest przyjaznym kompanem, czy wybuchnie krzykiem o głupstwo? Mama coraz częściej płakała ${ }^{62}$.

W zapisku z końca maja I942 roku osoba ojca jest wspomniana przy okazji notatek z bezsennej dusznej nocy w getcie, a miesiąc później, gdy Korczak rejestruje swój dziwny sen. Wraca wreszcie ojciec w ostatnim fragmencie pierwszej części Pamiętnika (pierwsza połowa lipca 1942), gdzie syn wyznaje:

\Bałem się panicznie szpitala wariatów, do którego ojciec mój parokrotnie był kierowany.

A więc ja, syn obłąkanego. A więc dziedzicznie obarczony ${ }^{63}$.

Hanna Mortkowicz-Olczakowa, pisząc krótko o chorobie Józefa Goldszmita, stwierdza, że przebywał między innymi w podwarszawskim szpitalu psychiatrycznym w Tworkach. Informacja ta jest dziś trudna do zweryfikowania. Z mo-

60 Ibidem, s. 45.

61 J. Olczak-Ronikier, Korczak. Próba biografii, s. 63.

62 Ibidem, s. 64-65.

63 J. Korczak, Pamiętnik i inne pisma z getta, s. 107. 
ich ustaleń wynika, że najstarsze zachowane dokumenty medyczne tej placówki pochodzą z początku XX wieku (a Józef zmarł w roku i896); większość zaginęła po ewakuacji szpitala w czasie drugiej wojny światowej. Dokumentacja medyczna pacjentów szpitali warszawskich miała jeszcze mniejsze szanse przetrwania. Zatem raczej nie dowiemy się już, jaka konkretnie była diagnoza dotycząca choroby mecenasa Goldszmita. Niemniej cytowany fragment Pamiętnika Korczaka może posłużyć na obronę jego imienia przed bardzo daleko idącymi insynuacjami ostatniej biografki pisarza. Joanna Olczak-Ronikier stawia bowiem tezę, że przyczyną obłędu Józefa był syfilis, jako „efekt przypadkowych przygód”, czego Henryk musiał się jej zdaniem domyślać. Jednak gdyby rzeczywiście tak było, syn nie obawiałby się obciążenia genetycznego. Jako lekarz musiał wiedzieć, że choroby będącej następstwem innego schorzenia nabytego przez ojca w dorosłości syn nie może odziedziczyć! Józef nie mógłby przekazać synowi w genach obłędu, który byłby efektem ubocznym choroby wenerycznej. Olczak-Ronikier sugeruje dalej, że mecenas Goldszmit mógł popełnić samobójstwo. Również ten domysł nie został wsparty żadnym argumentem. Choroby psychiczne często prowadzą do wyniszczenia organizmu i w konsekwencji do śmierci. Może Józef cierpiał na chorobę afektywną dwubiegunową albo schizofrenię (obie są dziedziczne). Tego się już raczej nie dowiemy. Ale sugestie prezentowane lekką ręką przez autorkę Próby biografii szybko przyjęły się w powszechnym odbiorze. Czytelnik wierzy narracji, ze wszystkimi konsekwencjami, jakie niesie to dla interpretacji postaci głównego bohatera biografii. W cytowanej wyżej recenzji Justyna Sobolewska relacjonuje „odkrywcze” fragmenty Próby biografi, dotyczące relacji Henryka z ojcem, w uproszczonym skrócie:

\section{\Na jego dzieciństwie położyła się cieniem choroba ojca, adwokata i bon vivanta, który miał syfilis i oszalał. Korczak stał się jego przeci- wieństwem - zrezygnował ze związków z kobietami i z dzieci ${ }^{64}$.}

Zwróćmy w tym kontekście uwagę na ostatnie wspomnienie ojca w Pamiętniku. Kilkanaście dni przed śmiercią pisarz zanotował:

1) Winienem wiele miejsca poświęcić ojcu: realizuję w życiu to, do czego on dążył, do czego dziadek tak dręcząco dążył tyle lat. [...] Jestem i matką, i ojcem. Wiem i wiele dzięki temu rozumiem ${ }^{65}$.

64 J. Sobolewska, Za murem...

65 J. Korczak, Pamiętnik i inne pisma z getta, s. 122. 
Wydaje się, że fragment ten nie stał się dotąd przedmiotem głębszej refleksji. Jak podkreślałam, ojciec jest osobą najczęściej wspominaną w Pamiętniku. Swoista „autobiografia” Korczaka stanowi przeplatankę wspomnień, refleksji i zapisków bieżących. Czyż można zignorować to, że zarówno pierwsze, jak i ostatnie wspomnienie w tym tekście dotyczy Józefa Goldszmita? Pierwsze zapowiada pogłębione reminiscencje, ostatnie jest wyrazem poczucia winy, że jako syn nie poświęcił ojcu w zapiskach więcej miejsca. Korczak w przededniu swojej śmierci stwierdza wprost, że jego życie było ni mniej, ni więcej, tylko realizacją dążeń i przekonań ojca, a w dalszej kolejności także dziadka i matki.

Wydaje się, że dokładna analiza wpływu Józefa Goldszmita na wybór drogi życiowej jego syna jest nieunikniona. Ta postać może się prezentować zupełnie inaczej, jeśli oprzemy się na „dowodach filologicznych”. Mecenas Goldszmit pozostawił po sobie ślady, które przeczą jednostronnemu, uproszczonemu, wysnutemu z wyobraźni wizerunkowi wykreowanemu przez Ronikier. Obok zapisków syna dysponujemy wszak także tekstami autorstwa Józefa, które mogą być świadectwem jego ambicji i zapatrywań. W wydanej niedawno książce O prawo do szacunku. Wybór pism Józefa i Jakuba Goldszmitów prócz faktograficznego biogramu można znaleźć całkiem pokaźny zbiór artykułów prasowych i broszur, które Józef pisał jeszcze jako student prawa Cesarskiego Uniwersytetu Warszawskiego (czy wcześniej Szkoły Głównej Warszawskiej) ${ }^{66}$. Są wśród nich obszerne życiorysy Izraelitów, którzy działalnością dobroczynną przyczynili się do poprawy warunków życia swoich współwyznawców, jednocześnie prezentując postawy obywatelskie wobec krajów, w których przyszło im żyć (Sir Moses Montefiore - Anglia; Achilles Fould i Albert Cohn - Francja). Znajdziemy obrazek Córka handlarza, oparty na autentycznych przeżyciach Józefa Goldszmita - młodego studenta uczestniczącego podczas epidemii cholery w Warszawie w 1866 roku w pracy komitetów ratunkowych. Poznał w tym czasie nędzę życia najbiedniejszych warstw społecznych. Znajdziemy następnie szereg studiów historycznych dotyczących losów Żydów w Hiszpanii i we Włoszech. Świadczą one nie tylko o głębokiej erudycji ich autora, ale pokazują też jego badawcze, naukowe inklinacje, zwieńczone później znakomitą pracą magisterską o rozwodach w prawodawstwie mojżeszowo-talmudycznym. Dysertacja wyróżniona przez władze Wydziału Prawnego jako „odznaczająca się źródłowym i samodzielnym opracowaniem" ${ }^{67}$, wydana w 1871 roku w drukarni Gebethnera i Wolffa, miała motto: „Prawa krajowe są dla Żydów tak obowiązujące, jak ich własne”. I była ostatnią ważną wypowiedzią mecenasa Goldszmita.

66 J. Goldszmit, J. Goldszmit, O prawo do szacunku. Wybór pism, Warszawa 2018.

67 J. Goldszmit, Wyktad prawa rozwodowego podtug ustaw mojżeszowo-talmudycznych z ogólnym poglqdem na ich rozwój z uwzględnieniem przepisów obowiqazujących, Warszawa 1871. 
\Uczony, pragnący posunąć naprzód gałąź wiedzy, która jest jego specjalnością, ustąpić musi przed ojcem nieustannie myślącym o dobru dzieci swoich ${ }^{68}$.

- pisał w jednym z artykułów. I wybrał rodzinę. Ożenił się krótko po studiach, a będąc człowiekiem nieprzeciętnego intelektu, zrobił karierę jako adwokat. Zanim jednak obrał własną drogę życiową, zostawił niejedną wskazówkę swojemu synowi. Tak dziś możemy odczytywać słowa Józefa Goldszmita:

\Pomiędzy zawodami najwznioślejszymi, jakie otwarte dziś są dla młodzieży, niejeden zapewne obierze sobie powołanie przewodniczenia innym w kształtowaniu umysłu i serca, posłannictwo jedno z najpiękniejszych, jedno z najbardziej odpowiadających celom i drogom ducha ludzkiego - nauczycielstwo ${ }^{69}$.

W innym artykule Józefa o ochronce dla dziewcząt izraelskich czytamy:

\ Ekonomia polityczna dowiodła, że do najpotężniejszych czynników dobrobytu należy podniesienie moralności i krzewienie nauki, a jako środki pomocnicze do tych celów wiodące wskazała zakłady opiekuńcze dla dzieci i naukowo-elementarne. Przyczynianie się więc do rozwoju takich zakładów jest obowiązkiem obywatelskim ciążącym zarówno na wszystkich w miarę sił i możności każdego ${ }^{70}$.

Syn autora tych słów podjął temat zakładów opiekuńczych dla dzieci izraelskich w sposób, który być może przerósł wyobrażenia ojca. Mecenas Goldszmit zmarł za wcześnie, żeby móc się przekonać, jaki kwiat i owoc wydadzą soki mozolnie zbierane przez pokolenia w tej rodzinie. A pisząc życiorys Montefiorego, nie mógł wiedzieć, że wiele fragmentów będzie można po latach odnaleźć w życiorysie jego syna, Henryka Goldszmita - Janusza Korczaka:

\ Przyjaciel ludzkości w całym słowa tego znaczeniu, zawsze śpieszy z pomocą uciśnionym i będącym w potrzebie. [...] Zamysłów jego i działalności nie trzeba ozdabiać aureolą chwały, w samej ich na-

68 Idem, Eukasz Koncewicz, „Tygodnik Ilustrowany” 1868, nr 5. Tekst został podpisany w spisie treści numeru nazwiskiem Goldszmit; w Wyborze pism mylnie przypisano jego autorstwo Jakubowi Goldszmitowi.

69 Ibidem.

70 J. Goldszmit, [w rubryce Korespondencja:] Lublin, dnia 6 września 1866 roku, „Izraelita” 1866, nr 24. 
turze i sposobie wykonania leży niewysłowiony urok i szczytność. Najpiękniej brzmiące biografie, najświetniejsze zaszczyty niczym są wobec otartych łez mnóstwa, wobec cichych dziękczynień za odebrane dobrodziejstwa, które jak woń kadzidła unoszą się ku niebu, wobec własnego przekonania wreszcie, o sumiennie dopełnionej podróży żywota, o pracowitym spełnieniu podjętej misji. [...] Prosty duchem, szczery dla potrzebujących jego pomocy, pełen poświęcenia dla nieszczęśliwych, skromny, mimo położonych zasług, stoi on przed nami jako wzór godny naśladowania ${ }^{71}$.

Wcześniej jeszcze, jako uczeń liceum lubelskiego, Józef Goldszmit składał publicznie „wyrazy wdzięczności i uwielbienia dla [...] współrodaków chrześcijan, którzy z narażeniem własnego życia ratowali pogorzelców wyznania mojżeszowego" podczas pożaru w Lublinie w $1862 \mathrm{roku}^{72}$. Albowiem zgodne wspólistnienie obu narodów żydowskiego i polskiego na równych prawach było założeniem zwolenników Haskali, a więc już dziadka Korczaka, potem jego ojca i stryja Jakuba, których cała twórczość została podporządkowana temu jednemu celowi:

Chęć służenia poczciwej sprawie wzajemnego zbliżenia oraz bliższego
poznania się jednej ziemi mieszkańców; [...] przyczynienia się o ile
możności do usunięcia istniejących jeszcze po dziś dzień pomiędzy
Izraelitami odrębności; utrwalenia wreszcie harmonii, jaka niezakłó-
cenie od wieków całych szeregu na ojczystej naszej panuje ziemicy³.

Korczak był Żydem. I był także Polakiem. Zgodnie ze wskazaniami ojca - „wzorowym obywatelem kraju swego"74. Był Żydem-Polakiem albo Polakiem-Żydem. Być może w tej dwoistej tożsamości w najgłębszym sensie zrealizował to, do czego jego ojciec zmierzał. Do czego dziadek Hersz Goldszmit „tak dręcząco dążył przez tyle lat"75. Z całą pewnością gruntowna analiza wczesnej twórczości Józefa Goldszmita może w dużym stopniu odsłonić duchowe i ideowe korzenie później-

71 Idem, Wizerunki wstawionych Żydów XIX wieku. I. Sir Moses Montefiore, Warszawa 1867, s. 5.

72 Idem, [w rubryce Korespondencje:] Lublin, dnia 16 listopada 1862 roku, „Jutrzenka” 1862, nr 48.

73 Idem, Kalendarz dla Izraelitów na Rok Religijny (Zwyczajny) od Stworzenia Świata 5642, czyli od Narodzenia Chrystusa 1881-1882, Warszawa 1881.

74 Idem, Wizerunki wstawionych Żydów..., cyt. za: J. Goldszmit, J. Goldszmit, O prawo do szacunku..., s. 349 .

75 Analizę doświadczenia dwoistej tożsamości autora Króla Maciusia Pierwszego zawiera tekst Bożeny Wojnowskiej Dlaczego „Janusz Korczak”? Rodowód pseudonimu, tradycja rodzinna, „Pamiętnik Literacki” 2019, z. 2. 
szych dokonań jego syna, autora znamiennych słów: „Dziecinne lata są górami, w których rzeka życia bierze swój początek, rozpęd i kierunek: jak śmiemy je lekceważyć?" 7 .

Rzetelna próba odtworzenia atmosfery, w której dorastał Henryk, to niełatwe zadanie, jednak jej rekonstrukcja na podstawie źródeł ma nieocenioną wartość. Poczynione przeze mnie w ostatnich latach badania dokumentacyjne zaowocowały wieloma zaskakującymi odkryciami, które mogą posłużyć za twardy grunt do stawiania hipotez. Jeśli na przykład chcieć szukać dramatycznych przeżyć, które mogły mieć wpływ na klimat domu, w którym dorastał autor Prawa dziecka do szacunku, to prócz choroby ojca, o której wiadomo bardzo niewiele, nie można pominąć śmierci młodszej siostry Henryka i Anny. Ustaliłam bowiem, że matka Korczaka, Cecylia Goldszmit, I2 lutego I882 roku urodziła jeszcze jedno dziecko. Dziewczynka przyszła na świat martwa, o szóstej wieczorem w warszawskim mieszkaniu Goldszmitów. $Z$ aktu sporządzonego dzień później wynika, że zgłoszenia dokonał Józef Goldszmit, adwokat przysięgły77. Mały Henryk miał wówczas trzy albo cztery lata. Pół roku wcześniej ojciec zarejestrował w urzędzie także jego. Być może bezpośrednim impulsem do załatwienia tej zaległej sprawy była właśnie kolejna ciąża żony.

Jaki wpływ mogło mieć to wydarzenie na całą rodzinę? Oczywiście umieralność noworodków i w ogóle dzieci pod koniec XIX wieku była znacznie wyższa niż dziś i być może doświadczający jej rodzice przeżywali to w inny sposób. Faktem jest wszakże, że mały Henryk był świadkiem wyczekiwania dziecka, a potem prawdopodobnie żałoby po jego stracie ${ }^{7}$.

W odnalezionych kilka lat temu listach stryja Korczaka, Jakuba Goldszmita, do Józefa Kraszewskiego i Elizy Orzeszkowej odnajdujemy świadectwo głębokiej traumy po śmierci innego dziecka w tej rodzinie. Otóż kilka miesięcy po siostrze Korczaka (której nie nadano imienia) odeszła jego dziesięcioletnia kuzynka, Anna Henryka, jedyne dziecko stryja Jakuba. Tragedii tej nie przetrwało małżeństwo stryja, jak wiemy ze wspomnianej korespondencji, on sam zapadł na wiele miesięcy na zdrowiu, a kilka lat później był już za oceanem, na emigracji w Ameryce Północnej ${ }^{79}$. Nie przesądzając więc o konsekwencjach, jakie mogła wywołać śmierć

76 J. Korczak, Stowo wstępne [do rozprawy Jędrzeja Śniadeckiego] „O fizycznym wychowaniu dzieci”..., s. 13.

77 Zob.akt nr 15 https://szukajwarchiwach.pl/72/200/0/-/17/str/0/81/1\#tabSkany (stan z 23 października 2020 r.).

78 Ukochana babcia Emilia (ze strony matki), którą Korczak z czułością wspomina na kartach pamiętnika, a która w tym czasie mieszkała z Goldszmitami, także miała za sobą podobne przejścia. Dalsze poszukiwania archiwalne doprowadziły mnie do odkrycia innych śmierci dzieci w tej rodzinie. Matka Korczaka również miała młodszą siostrę, która zmarła przy porodzie, jeden z braci babci Emilii żył zaledwie dziewięć miesięcy, brat dziadka Józefa (Adolfa) umarł w wieku ośmiu lat.

79 Listy w opracowaniu Bożeny Wojnowskiej zob. „Pamiętnik Literacki” 2013, z. 4 oraz 2015, z. 3. 
młodszej siostry Korczaka, pragnę podkreślić, że odnalezienie jej metryki poszerza perspektywę patrzenia na dzieciństwo, czyli okres formacyjny przyszłego wielkiego pedagoga i myśliciela, który pisał później także o prawie dziecka do... śmierci.

Czytelnik Próby biografii nie dowie się o istnieniu siostry, a i o stryju Jakubie Goldszmicie znajdzie tam tylko krótką notkę. Tymczasem ten niezwykle aktywny na polu działalności publicystycznej i społecznej brat Józefa niewątpliwie był częścią dzieciństwa Henryka. W latach I880-1887 mieszkał w Warszawie, bywał w domu brata, znał dobrze jego teściów, o czym świadczy chociażby zamieszczone w kalendarzu „Warszawianin” wspomnienie pośmiertne o Józefie (Adolfie) Gębickim, autorstwa Jakuba Goldszmita ${ }^{80}$. We wstępie do wymienionego wydania wyboru tekstów Józefa i Jakuba Goldszmitów, charakteryzującym prezentowane tam materiały, czytamy:

\Natykamy się tu na problem pogranicza kultury polskiej i żydowskiej, proces osadzania się, wymiany i dialogu konkretnych elementów tych kultur w zachowaniach ludzi z najbliższego otoczenia Henryka Goldszmita [...]. Lektura tych wypowiedzi, łącznie z ich macierzystym kontekstem, umożliwia poznanie środowiska życiowego rodziny Goldszmitów. Przybliża atmosferę, w jakiej wzrastał od dzieciństwa przyszły pisarz i pedagog. Umożliwia uchwycenie owych subtelnych, nieokreślonych momentów, które kształtują człowieka od lat najmłodszych. Korczak określał je jako niepowtarzalny „teren wychowawczy”, „duszę rodziny, która panuje" ${ }^{\text {rr }}$.

Zatem rzetelna analiza także tych materiałów może stanowić przyczynek do charakterystyki źródeł intelektualnych i szerzej kulturowych, z których wyrosły pisarstwo i działalność Korczaka. Bez rozwinięcia tego wątku obraz pozostaje niepełny.

W swojej próbie dotarcia „do korzeni” pominęła Ronikier etap kwerend archiwalnych i krytyki źródeł. Obraz rodzinnych uwarunkowań Korczaka przedstawiony w jej książce jest subiektywny, nieudokumentowany, jednostronny i wysnuty z fantazji. Trudno jednak jej taktykę nazwać błędem metodologicznym, ponieważ Próba biografii nie jest monografią naukową. Podobnie jak Prus. Śledztwo biograficzne Moniki Piątkowskiej czy na przykład książka Hanny Mortkowicz-Olczakowej O Stefanie Żeromskim. Ze wspomnień i dokumentów ${ }^{82}$. Pozycje te są niejako stylizowane na publikacje naukowe, zawierają szereg strategii mających potwierdzać wiarygodność narracji, ale to czytelnik popełni błąd, jeśli im zawierzy do końca.

80 J. Goldszmit, Z Lublina do Ciechocinka. Kartki z podróży, „Gazeta Lubelska” 1877, nr 100.

81 B. Wojnowska, Wstęp, w: J. Goldszmit, J. Goldszmit, O prawo do szacunku..., s. 5.

82 H. Mortkowicz-Olczakowa, O Stefanie Żeromskim. Ze wspomnień i dokumentów, Warszawa 1965. 
Szczególnie czytelnik profesjonalny, badacz, historyk czy krytyk literacki ${ }^{83}$. Jeśli bowiem budujemy interpretacje $\mathrm{w}$ odniesieniu do niepewnych danych, mamy małe szanse zbliżyć się do prawdy.

Konsekwentnie podtrzymuję twierdzenie, że bez rzetelnych kwerend źródłowych, bez weryfikacji tez uznawanych za oczywiste i bez powrotu do filologicznego warsztatu najważniejszych tekstów Korczaka, poszerzenie i pogłębienie wiedzy o tej postaci jest trudne lub wręcz niemożliwe. Kolejne, skądinąd atrakcyjne dla masowego czytelnika, interpretacje życia Starego Doktora nie zastąpią faktograficznych ustaleń. Posłużę się w tym miejscu pewną analogią. Edytor, który przygotowuje wydanie powieści (nawet jeśli tylko popularne), powinien dokonać elementarnych zabiegów zmierzających do ustalenia poprawnego tekstu. Jeśli za podstawę wydania wybierze wersję skażoną błędami lub (co gorsza) skompiluje kilka wybranych przekazów, a luki uzupełni własną inwencją twórczą - wprowadzi do publicznego obiegu hybrydę, która odtąd będzie konkurować z odautorskimi wariantami utworu. Podobnie rzeczywistość wykreowana w literackiej lub paranaukowej biografii zapada w pamięć czytelników i przesłania historyczne realia. Kiedy hipotezy graniczące z fantazją - atrakcyjne dla masowej wyobraźni - zostają uznane za pewniki, próba wyjaśnienia meandrów biograficznych wiedzie na manowce.

\section{BIBLIOGRAFIA}

Adamczyk Z.J., Manipulacje i tajemnice. Zagadki późnej biografii Stefana Żeromskiego, Warszawa 2017.

Bąbel A., Przygwożḋenie wiewiórem, „Tygodnik Powszechny” 2018, nr 4.

Bikont A., Korczak, „Zeszyty Literackie”2011, nr 3.

Buhler A., L'adieu aux enfants, Paris 1978.

Dębnicki K., Korczak z bliska, Warszawa 1985.

Falkowska M., Kalendarz życia, dziatalności i twórczości Janusza Korczaka, Warszawa 1989.

Gliński M., 12 rzeczy o Korczaku, które warto wiedzié,, https://culture.pl/pl/artykul/12-rzeczy-o-korczaku-ktore-warto-wiedziec.

Goldszmit Józef, Goldszmit Jakub, O prawo do szacunku. Wybór pism, Warszawa 2018.

Goldszmit Jakub, Kraszewski J.I., Listy, oprac. B. Wojnowska, „Pamiętnik Literacki”2013, z. 4.

Goldszmit Jakub, Orzeszkowa E., Listy, oprac. B. Wojnowska, „Pamiętnik Literacki” 2015, z. 3.

83 W takiej sytuacji znalazł się na przykład Zdzisław Jerzy Adamczyk. Ten wybitny badacz twórczości Żeromskiego, zasłużony edytor jego pism przyznaje, że gdy przystępował do pracy nad wydaniem listów autora Przedwiośnia, jego wiedza o życiu pisarza była ukształtowana przez lekturę książki Mortkowicz-Olczakowej oraz wspomnień córki pisarza, Moniki Żeromskiej. Dopiero poszukując informacji potrzebnych dla objaśnienia korespondencji autora Wiernej rzeki w archiwach i bibliotekach, zorientował się, jak bardzo daleki od rzeczywistości jest utrwalony w powszechnej świadomości obraz ostatnich lat życia Żeromskiego. Książka Adamczyka Manipulacje i tajemnice. Zagadki późnej biografii Stefana Żeromskiego (Warszawa 2017) jest próbą odkłamania utartych przekonań i przywrócenia należnego miejsca faktom. 
Goldszmit Jakub, Z Lublina do Ciechocinka. Kartki z podróży, „Gazeta Lubelska” 1877, nr 100.

Goldszmit Józef, Kalendarz dla Izraelitów na Rok Religijny (Zwyczajny) od Stworzenia Świata 5642, czyli od Narodzenia Chrystusa 1881-1882, Warszawa 1881.

[W rubryce Korespondencje:] Lublin, dnia 16 listopada 1862 roku, „Jutrzenka” 1862, nr 48.

[W rubryce Korespondencja:] Lublin, dnia 6 września 1866 roku, „Izraelita” 1866, nr 24.

Eukasz Koncewicz, „Tygodnik Ilustrowany” 1868, nr 5.

Wizerunki wstawionych Żydów XIX wieku. I. Sir Moses Montefiore, Warszawa 1867.

Wyktad prawa rozwodowego podtug ustaw mojżeszowo-talmudycznych z ogólnym pogladem na ich rozwój z uwzględnieniem przepisów obowiq̨zujących, Warszawa 1871.

Jaworski M., Janusz Korczak, Warszawa 1973, wyd. drugie 1977, wyd. trzecie 1978.

Kola A.M., Korczak odczytany na nowo, „Praca Socjalna” 2012, nr 2.

Korczak J., Dedykacja, w: idem, Sam na sam z Bogiem, Warszawa 1922.

Pamiętnik i inne pisma z getta, Warszawa 2012.

Stowo wstępne [do rozprawy Jędrzeja Śniadeckiego] „O fizycznym wychowaniu dzieci”, Warszawa 1920, przedruk w: idem, Dzieta, t. 13, Warszawa 2016.

Trzy wyprawy Herszka, Warszawa 1939, przedruk w: idem, Dzieta, t. 12, Warszawa 1998.

Lewin A., Korczak znany i nieznany, Warszawa 1999.

Lifton B.J., The king of children, New York 1988.

Łapicka K., O czym śni motyl?, http://zteatru.pl/2017/11/15/ateneum/.

Martuszewska A., Prus zdegradowany, „Pamiętnik Literacki” 2018, z. 3.

Mortkowicz-Olczakowa H., Janusz Korczak, Warszawa 1949 i wyd. nast., m.in. wyd. od drugiego do piątego w 1957-1978.

O Stefanie Żeromskim. Ze wspomnień i dokumentów, Warszawa 1965.

Newerly I., Żywe wiazanie, Warszawa 1966, wyd. drugie 1967, wyd. trzecie 1971.

Olczak-Ronikier J., Korczak. Próba biografi, Warszawa 2011, wyd. nast. 2012.

Piątkowska M., Prus. Śledztwo biograficzne, Kraków 2017.

Ratajczak W., O potrzebie wierności drobiazgom, „Poznańskie Studia Polonistyczne. Seria Literacka” 2019, nr 35 (55).

Romanowski M., Biograficzne "punctum”. Pisarstwo biograficzne Joanny Olczak-Ronikier w perspektywie tożsamościowej, ,Teksty Drugie” 2019, nr 1.

Sęczek M., Uwolnić Korczaka? Zagadnienie praw autorskich do spuścizny autora „Króla Maciusia Pierwszego", w: Literatura w granicach prawa (XIX-XX w.), red. K. Budrowska, E. Dąbrowicz i M. Lul, Warszawa 2013.

Sobolewska J., Za murem, „Polityka” 2011, nr 24.

Szlązakowa A., Janusz Korczak, Warszawa 1978.

Szybowicz E., Zapomnij o świętym Korczaku, https://www.dwutygodnik.com/artyku1/2321-zapomnij-o-swietym-korczaku.html.

Witkowska A., Biografia spetniona, „Cwisz[y]n” 2011, nr 4.

Wojnowska B., Dlaczego „Janusz Korczak”? Rodowód pseudonimu, tradycja rodzinna, „Pamiętnik Literacki” 2019, z. 2.

Wstęp, w: J. Goldszmit, J. Goldszmit, O prawo do szacunku. Wybór pism, Warszawa 2018. 
Marlena Sęczer Ślady zapomnianej tożsamości. O roli źródeł w biografii Janusza Korczaka

Wołodźko K., Korczak. Życiorys niesentymentalny, „Rzeczpospolita” 2014, dod. „Plus Minus”, nr 29 oraz ibidem 2017, https://www.rp.pl/Plus-Minus/307189987-Korczak-zyciorys-niesentymentalny.html.

Wołoszyn S., Korczak, Warszawa 1978, wyd. drugie 1982.

Z.P., Wspomnienie posmiertne, „Izraelita” 1877, nr 23.

STRONY INTERNETOWE

https://nplp.pl/artykul/drzewo-genealogiczne-osoby/

http://nplp.pl/artykul/karol-gebicki/

http://nplp.pl/artykul/anna-goldszmit/

https://szukajwarchiwach.p1/72/200/0/-/17/str/0/81/1\#tabSkany.

SŁOWA KLUCZE: Janusz Korczak, biografia, genealogia, badania archiwalne

\section{TRACES OF FORGOTTEN IDENTITY. ON THE ROLE OF SOURCES IN THE BIOGRAPHY OF JANUSZ KORCZAK}

The figure of Henryk Goldszmit (Janusz Korczak) is the topic of many bibliographical publications. In the face of a lack of strictly scholarly works in this field, texts, in which the boundary between fact and author's interpretation is very fluid, seem to gain more importance. The aim of the article is to point out the issues stemming from this, and to highlight the importance of bibliographical works based on archival research and reliable criticism of sources. Juxtaposing the first chapters of An Attempt at a Biography by Joanna Olczak-Ronikier with a documentary take on the genealogy of the Old Doctor allows one to state that even those narratives, which are the most suggestive and attractive to the reader, cannot fill the gaps in historical knowledge. Without referring to the archives, verifying arguments regarded as obvious, or without a philological reflection on the texts by Korczak, the chances to correct the errors which build up and shape the contemporary reception of the legacy of Henryk Goldszmit, diminish.

KEY wORDs: Janusz Korczak, biography, genealogy, archival research 